\title{
Clinicopathological characteristics of oral squamous cell carcinoma in Northern Norway: a retrospective study
}

Oddveig G Rikardsen ${ }^{1,2}$, Inger-Heidi Bjerkli ${ }^{1}$, Lars Uhlin-Hansen ${ }^{2,3}$, Elin Hadler-Olsen ${ }^{2,3}$ and Sonja E Steigen ${ }^{2,3^{*}}$

\begin{abstract}
Background: The main aim of the study was to evaluate if patients with oral squamous carcinomas in Northern Norway differ from patients in other countries with regard to clinicopathological characteristics and also study the influence of risk factors. Such a comparison is of demographical interest, and also important for the interpretation of result from studies on prognostic biomarkers.

Methods: We describe clinicopathological characteristics of 133 North Norwegian patients diagnosed with squamous cell carcinoma of the oral cavity in the period 1986-2002, and evaluate the significance of different risk factors.

Results: The cohort consisted of 69 men and 64 women, giving male/female ratio of 1.1. Forty-seven of the 133 patients (35\%) died of the disease within 5 years from diagnosis. There was no significant difference between the genders concerning time to disease specific death, even though men both smoked and drank more alcohol than women. As expected, the strongest predictors for disease specific death were tumour size and the presence of regional lymph node metastasis. We also found that heavy smokers and drinkers presented with more advanced disease, more often localized to the floor of mouth compared to non-smoking and abstinent patients, who more often presented with tumours of the mobile tongue.

Conclusions: Our results correlate well with previously published clinicopathological data on comparable cohorts, which is important when considering the applicability of results from biomarker studies performed on this material compared to other cohorts, and vice versa.
\end{abstract}

Keywords: Oral squamous cell carcinoma, Smoking, Alcohol, Primary site, Gender

\section{Background}

Squamous cell carcinoma (SCC) accounts for more than $90 \%$ of the malignant neoplasm's in the oral cavity, which includes tongue, floor of mouth, buccal mucosa, alveolar rim and the hard and soft palate [1,2]. Globally, about 275,000 new cases of oral SCC (OSCC) are diagnosed each year [3], but the incidence of OSCC show large geographical variations. In the southern part of Asia and in Latin America the incidence of OSCC is about 20 fold higher than in Northern Europe, and is actually the

\footnotetext{
* Correspondence: sonja.steigen@unn.no

${ }^{2}$ Department of Medical Biology - Tumour Biology Research Group, UiT The Arctic University of Norway, Tromsø, Norway

${ }^{3}$ Diagnostic Clinic - Clinical Pathology, University Hospital of North Norway, Tromsø, Norway

Full list of author information is available at the end of the article
}

most common cancer among the male population in some of the high-risk areas in Asia [3].

The lifetime risk of developing oral or oropharyngeal cancer in Europe is estimated to be $1.85 \%$ for men and $0.37 \%$ for women [3]. Age-standardized incidence (rates per 100 000) for lip and oral cancer in Northern Europe is 5.1 for men and 2.5 for women [4]. In Norway the equivalent numbers are 4.3 and 2.5. In these numbers SCC of the lip accounts for approximately $40 \%$ of the cases [5]. The incidence rates are higher in Western and Eastern Europe than in northern or southern European countries; France and Hungary presenting the highest numbers, Greece and Cyprus the lowest [6,7]. In Northern France, the oral cavity and oropharynx constitute the second most common cancer sites in men, after lung [8]. 
The large geographical variations in incidence are mainly explained by cultural differences which is influenced by the exposure to risk factors [2]. The two best known risk factors in the Western countries are tobacco and alcohol abuse, which act strongly synergistically, and are estimated to account for up to $75 \%$ of the disease burden in this part of the world [7,9-11]. Koch et al. reported that cigarette smoking increased the risk for OSCC 1.9 times in men and 3 times in women. For persons who stop smoking, the risk falls to non-smoker level in 10 years. Daily drinkers (2 units/day) are reported to have an increased oral cancer risk of 1.7 , heavy drinkers up to 3 . For persons who smoke and drink alcohol daily, the odds ratio are reported to be as high as 35 [12,13]. In Southern Asia the chewing of betel quid and areca nuts explains the high incidence $[14,15]$. The exposure to various risk factors also has impact on the primary site of OSCC, betel quid and areca nut chewing mainly disposing for tumours arising in the buccal mucosa, while cigarette smoking and alcohol are disposing for tumours in the floor of mouth [1,12,16-18].

The most widely used classification-system for describing the anatomical extent of the disease is the Union for International Cancer Controls TNM-system [19] which grades primary tumour size and invasion features $(\mathrm{T})$, regional lymph node spread $(\mathrm{N})$ and the presence of distant metastasis (M). Survival time of the OSCC patients is strongly associated with the TNM-stage, and the TNMclassification system is still the most important guide for treatment stratification in clinical practice [20,21]. By morphological assessment, tumours are classified based on the cancer cells differentiation into well, moderately and poorly differentiated carcinomas [1]. Some report that patients with well differentiated tumours live longer than patients with low differentiated tumours [22,23], whereas other report poor correlation between outcome and tumour grade [24,25].

The acquired knowledge about the impact of human papilloma virus (HPV) infection in oropharyngeal tumours highlights the importance of distinguishing oropharyngeal tumours from tumours in the oral cavity. An increasing number of the tumours arising in the oropharynx are thought to be HPV-driven. The behaviour and treatment response of these tumours differ to such a degree from HPV negative tumours that an increasing number of scientists claim that they should be considered as two different enteties [20,26]. In the oral cavity, though, HPV-related tumours are uncommon, and the HPVstatus of the tumour has little impact on outcome [27-29]. A tumour cell infected with an oncogenic HPV-type, overexpress the tumour suppressor protein p $16^{\text {INK4a }}$ due to retinoblastoma $(\mathrm{Rb})$ gene inactivation by the E7 oncoprotein [30]. In clinical practice the HPV status of a tumour is often determined indirectly by immunohistochemical identification of overexpression of the p16 protein [31,32].

In the present study we present a cohort of 133 OSCC patients from Northern Norway. The population of Northern Norway may be exposed to other risk factors than people in other cohorts. The main aim of the study was therefore to evaluate if patients with OSCC in Northern Norway differ from patients in other countries with regard to clinicopathological characteristics. Such a comparison is not only of demographical interest, but is also important for the interpretation of result from studies on prognostic biomarkers performed on this cohort to other populations, and for implementation of results from studies on other populations around the world to our patients.

\section{Methods}

\section{Specimens}

The cohort described in this paper consists of 133 patients collected from the archives of the Department of Clinical Pathology, University Hospital of North Norway. They represent all patients diagnosed at the department with primary SCC of the oral cavity (ICD-O, C02-C06) [33] in the period 1986-2002. Second primaries were excluded.

The relevant clinical data and the tumours' TNMclassification [19] were retrieved from patients files, including pathology reports and Statistics of Norway, Cause of Death Registry. The N-stage was based on clinical and radiological findings. The study was approved by the Regional committees for Medical and Health Research Ethics, Northern Norway (No. 22/2007).

\section{Immunhistochemical staining of p16}

Tissue microarray (TMA) blocks containing 2 cores of $0.6 \mathrm{~mm}$ from representative tumour tissue from all patients were sectioned at $4 \mu \mathrm{m}$ and transferred to Superfrost + slides. The immunohistochemical staining for p16 was done in the automated slide stainer Ventana Benchmark, XT (Ventana Medical Systems, Inc., Roche, Tucson Arizona, USA) at the Department of Clinical Pathology, University Hospital of North Norway, using the same protocols, and positive and negative controls as in the clinical routine. The antibody used was a prediluted mouse anti-p16, clone E6H4, Ventana, recognizing the tumour suppressor $\mathrm{p} 16^{\mathrm{INK} 4 \mathrm{a}}$ protein. The slides were pre-treated with cell conditioning $1(\mathrm{CC} 1)$ at $95^{\circ} \mathrm{C}$ for 36 minutes, and the antibody incubation time was 28 minutes.

The staining was recorded as percentage of tumour cells stained; (1 (<10\%), 2 (10-50\%), 3 (51-80\%) and 4 ( $>80 \%)$, and was performed by one experienced pathologist (SES) and one head and neck surgeon (OR). The scoring was easy to perform, as the majority of the tissue samples were either completely negative, or clearly 
Table 1 Clinicopathiological variables defined by gender and disease specific death (DSD)

\begin{tabular}{|c|c|c|c|c|c|c|}
\hline & & & Difference & & DSD & \\
\hline & $\begin{array}{c}\text { Men } \\
(n=69)\end{array}$ & $\begin{array}{l}\text { Women } \\
(n=64)\end{array}$ & $\begin{array}{c}\text { Gender } \\
\text { p-value* }\end{array}$ & $\begin{array}{c}\text { All patients } \\
(\mathrm{n}=133)\end{array}$ & $\begin{array}{c}\mathrm{N} \\
\text { (\% of total) }\end{array}$ & DSD p* \\
\hline \multicolumn{7}{|l|}{ Age } \\
\hline$\leq 50$ years & $8(12 \%)$ & $9(14 \%)$ & $p=0.405$ & $17(13 \%)$ & $4(24 \%)$ & 0.769 \\
\hline $51-60$ years & 19 (28\%) & $11(17 \%)$ & & $30(23 \%)$ & $12(40 \%)$ & \\
\hline $61-70$ years & $18(26 \%)$ & $14(22 \%)$ & & $32(24 \%)$ & $14(44 \%)$ & \\
\hline $71-80$ years & $15(22 \%)$ & $15(23 \%)$ & & $30(23 \%)$ & $9(30 \%)$ & \\
\hline$\geq 81$ years & $9(13 \%)$ & $15(23 \%)$ & & $24(18 \%)$ & $8(33 \%)$ & \\
\hline \multicolumn{7}{|c|}{ Tumor differentiation } \\
\hline Verrocous & $1(1 \%)$ & $4(6 \%)$ & $p=0.474$ & $5(4 \%)$ & 0 & 0.142 \\
\hline Well & $28(41 \%)$ & $28(44 \%)$ & & $56(42 \%)$ & $17(30 \%)$ & \\
\hline Moderate & $34(49 \%)$ & $27(42 \%)$ & & $61(46 \%)$ & $25(41 \%)$ & \\
\hline Poor & $6(9 \%)$ & $5(8 \%)$ & & $11(8 \%)$ & $5(45 \%)$ & \\
\hline \multicolumn{7}{|l|}{ Tumor stage } \\
\hline T1 & $19(28 \%)$ & $24(39 \%)$ & $p=0.335$ & $43(32 \%)$ & $8(19 \%)$ & $<0.001$ \\
\hline $\mathrm{T} 2$ & $25(36 \%)$ & $21(33 \%)$ & & $46(35 \%)$ & $11(24 \%)$ & \\
\hline T3 & $4(6 \%)$ & $7(11 \%)$ & & $11(8 \%)$ & 7 (64\%) & \\
\hline T4 & $18(26 \%)$ & $9(14 \%)$ & & $27(20 \%)$ & $17(63 \%)$ & \\
\hline Unknown & $3(4 \%)$ & $3(5 \%)$ & & $6(5 \%)$ & $4(67 \%)$ & \\
\hline \multicolumn{7}{|c|}{ Lymph node status } \\
\hline NO & $42(61 \%)$ & $40(63 \%)$ & $p=0.200$ & $82(62 \%)$ & $21(26 \%)$ & $<0.001$ \\
\hline $\mathrm{N}+{ }^{\mathrm{a}}$ & $21(30 \%)$ & $13(20 \%)$ & & $34(26 \%)$ & $21(62 \%)$ & \\
\hline Unknown & $6(9 \%)$ & $11(17 \%)$ & & $17(13 \%)$ & $5(29 \%)$ & \\
\hline \multicolumn{7}{|l|}{$\operatorname{SOD}^{b}$} \\
\hline Stage I & $15(22 \%)$ & $17(27 \%)$ & $p=0.316$ & $32(24 \%)$ & $4(13 \%)$ & $<0.001$ \\
\hline Stage II & 19 (28\%) & $16(25 \%)$ & & $35(26 \%)$ & $7(20 \%)$ & \\
\hline Stage III & $9(13 \%)$ & $11(17 \%)$ & & $20(15 \%)$ & $10(50 \%)$ & \\
\hline Stage IV & $20(29 \%)$ & $10(16 \%)$ & & $30(23 \%)$ & $21(70 \%$ & \\
\hline Unknown & $6(9 \%)$ & $10(16 \%)$ & & $16(12 \%)$ & $5(31 \%)$ & \\
\hline \multicolumn{7}{|l|}{ Primary site } \\
\hline Mobile tounge & $34(49 \%)$ & $27(42 \%)$ & $p=0.038$ & $61(46 \%)$ & $18(30 \%)$ & 0.548 \\
\hline Floor of mouth & $21(30 \%)$ & $9(14 \%)$ & & 30 (22\%) & $12(40 \%)$ & \\
\hline Alveolar rim & $9(13 \%)$ & $15(23 \%)$ & & $24(18 \%)$ & $8(33 \%)$ & \\
\hline Buccal mucosac & $4(6 \%)$ & $7(11 \%)$ & & $18(14 \%)$ & $9(50 \%)$ & \\
\hline Palate $^{c}$ & $1(1 \%)$ & $3(5 \%)$ & & & & \\
\hline Other & 0 & $3(5 \%)$ & & & & \\
\hline \multicolumn{7}{|l|}{ Smoking } \\
\hline Never & $8(12 \%)$ & $27(42 \%)$ & $p<0.001$ & 35 (26\%) & $9(26 \%)$ & 0.566 \\
\hline Previous smoker & $14(20 \%)$ & $6(9 \%)$ & & $20(15 \%)$ & $7(47 \%)$ & \\
\hline Smoker & $41(59 \%)$ & $18(28 \%)$ & & 59 (44\%) & $24(41 \%)$ & \\
\hline Unknown & $6(9 \%)$ & $13(20 \%)$ & & $19(14 \%)$ & $7(37 \%)$ & \\
\hline \multicolumn{7}{|c|}{ Alcohol consumption } \\
\hline Never & $5(7 \%)$ & $23(36 \%)$ & $p<0.001$ & $28(21 \%)$ & $6(21 \%)$ & 0.002 \\
\hline$<$ once a week & 27 (39\%) & $20(31 \%)$ & & 47 (35\%) & 16 (34\%) & \\
\hline
\end{tabular}


Table 1 Clinicopathiological variables defined by gender and disease specific death (DSD) (Continued)

\begin{tabular}{|c|c|c|c|c|c|c|}
\hline > once a week & $9(13 \%)$ & $1(2 \%)$ & & $10(8 \%)$ & $2(20 \%)$ & \\
\hline Daily & $8(12 \%)$ & $3(5 \%)$ & & $11(8 \%)$ & $7(64 \%)$ & \\
\hline Unknown & $20(29 \%)$ & $17(27 \%)$ & & $37(28 \%)$ & $16(43 \%)$ & \\
\hline \multicolumn{7}{|l|}{$\mathbf{I R F}^{\mathrm{d}}$} \\
\hline Non-smoker/non-drinker & $10(14 \%)$ & $30(47 \%)$ & $\mathrm{p}<0.001$ & $40(30 \%)$ & $10(25 \%)$ & \multirow[t]{4}{*}{0.120} \\
\hline Smoker/light drinker ${ }^{\mathrm{e}}$ & $22(32 \%)$ & $13(20 \%)$ & & $35(26 \%)$ & $12(34 \%)$ & \\
\hline Smoker/heavy drinker ${ }^{\mathrm{e}}$ & $17(25 \%)$ & $4(6 \%)$ & & $21(16 \%)$ & $9(43 \%)$ & \\
\hline Unknown & $20(29 \%)$ & $17(27 \%)$ & & $37(28 \%)$ & $16(43 \%)$ & \\
\hline \multicolumn{7}{|l|}{ P16-staus $^{f}$} \\
\hline Positiv & $6(10 \%)$ & $4(7 \%)$ & $p=0.625$ & $100(88 \%)$ & $38(33 \%)$ & \multirow[t]{2}{*}{0.791} \\
\hline Negative & 54 (90\%) & 50 (93\%) & & 10 (9\%) & $4(4 \%)$ & \\
\hline
\end{tabular}

aincludes N1, N2a, N2b, N2c and N3.

${ }^{\mathrm{b}} \mathrm{SOD}=$ Stage of Disease.

In the further analyses, these three are merged.

${ }^{\mathrm{d}} \mathrm{RF}=$ Intergrading risk factors.

elight drinker = less than once a week; heavy drinker = more than once a week or daily.

${ }^{\mathrm{f}} \mathrm{N}=114$ in the p16 analysis.

${ }^{*} p<0.05$ was regarded as statistically significant, and highlighted in boldface when present.

positive. In cases of disagreement the score was discussed and an consensus was achieved.

\section{Statistics and analyses}

The statistical analyses were performed using IBM SPSS statistics for Windows (IBM Corporation Armonk, New York), version 21. Associations between different categorical variables were assessed with Pearson's chi-square test and Pearson correlation. Comparing of means was done using the ONE-Way ANOVA-test. Univariate analyses of time from diagnosis to death were performed using the Kaplan-Meier method, and differences between categories were estimated by the log-rank test, with the date of diagnosis as starting point. The influence of covariates on patient survival was analysed by multivariate analysis (proportional hazard method). The last day of follow-up was 01.01.2012. All results were considered significant if $\mathrm{p} \leq 0.05$.

To control for variation due to age the patients were divided into five groups ( $\leq 50$ years, $51-60$ years, $61-70$ years, $71-80$ years and $\geq 81$ years). We also constructed a variable called "Integrading risk factors" (IRF) that combine the factors smoking and alcohol, and a factor called "Stage of disease" (SOD) that combined the T, N and $\mathrm{M}$-stage based on the American Joint Comitee on Cancer (AJCC) staging system [34].

\section{Results}

\section{Gender and age}

The cohort consisted of $52 \%$ men and $48 \%$ women, giving a male/female ratio of 1.1. All clinicopathological variables defined by gender and survival analyses are summarized in Table 1. The mean age at diagnosis was 66.3 years, 64.9 for men (range 29-93) and 67.7 (range 27-90) for women.
The mean overall survival from diagnosis was 56.7 months for men and 88.3 months for women, a difference that was statistically significant $(\mathrm{p}=0.021)$.

Forty-seven (35\%) of the 133 patients (35\%) died of the disease within 5 years from diagnosis, $41 \%$ of the men and $30 \%$ of the women. Although the women in general lived longer than the men, the difference in 5 years disease specific survival was not statistically significant $(\mathrm{p}=0.189$ ). There was a tendency that women were diagnosed with smaller tumours (lower T-stage) than men $(\mathrm{p}=0.078)$.

Nine patients $(7 \%)$ were younger than 45 years at the time of diagnosis, which completely coincide with what has been reported globally [6]. Three of these young patients died of the disease.

The risk of dying of the disease within 5 years was the same in all age-groups, see Table 1 . There was no significant association between age and primary site, grade of tumour differentiation, p16-status, tumour size $(\mathrm{T})$ nor the presence of regional metastasis $(\mathrm{N})$. However, the youngest and eldest patients smoked less tobacco $(\mathrm{p}=0.008)$, and consumed significantly less alcohol $(\mathrm{p}=0.002)$ compared to the middle-aged, see Figure $1 \mathrm{a}$ and $\mathrm{b}$.

\section{Anatomic site and classification}

The majority of the tumours arose in the mobile tongue (46\%), floor of mouth (23\%) and alveolar ridge (18\%) (Table 1). There was a significant correlation between gender and primary site $(\mathrm{p}=0.015)$, men accounting for $70 \%$ of the tumours in the floor of mouth, while tumours of the alveolar rim being most frequently diagnosed in women (63\%) (Table 2).

Most of the tumours were well $(41 \%)$ or moderately differentiated (46\%) and $4 \%$ of the tumours showed a verrucous growth pattern. There was a higher occurrence 


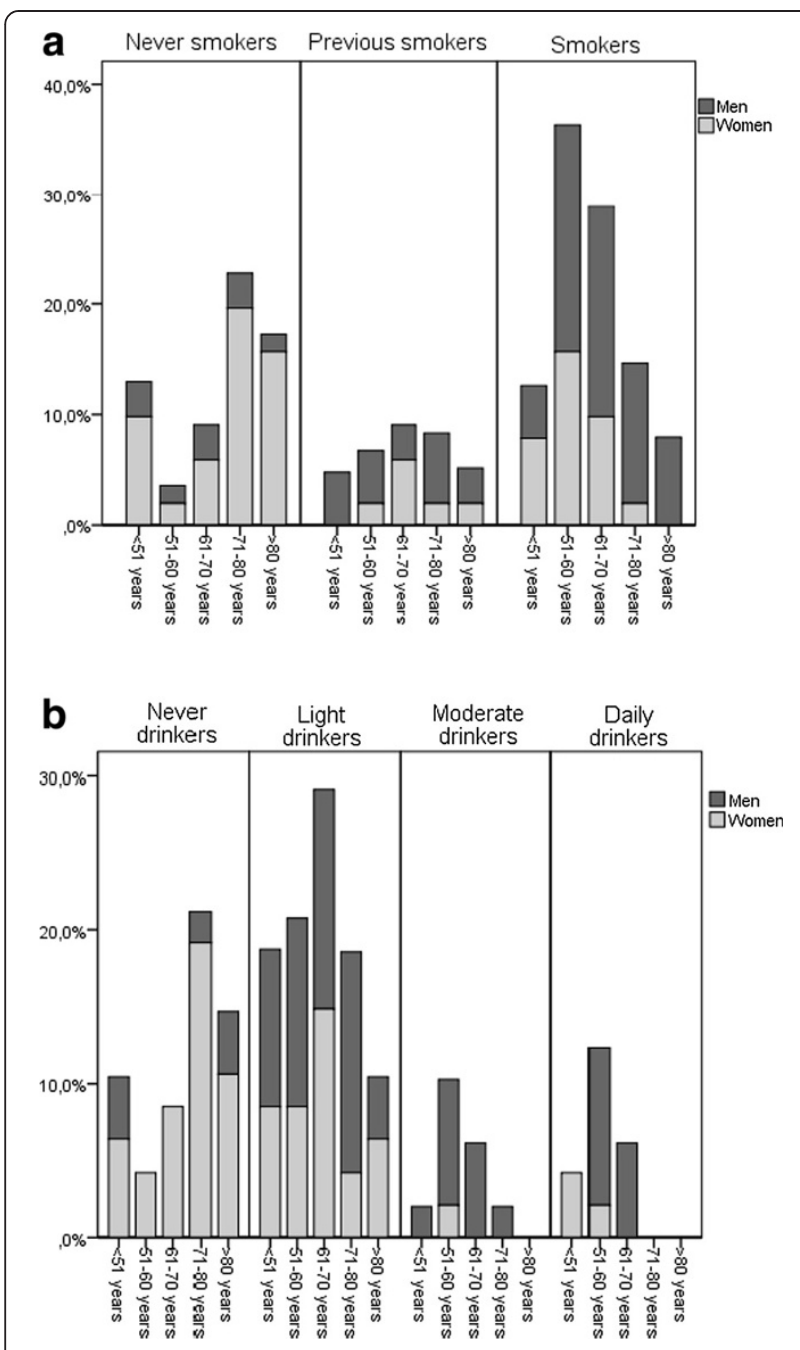

Figure $1 \mathrm{~A}$ graphical illustration of the relation between smoking (a) and alcohol consumption (b) in the different age-groups. The columns are split by gender.

of lymph node metastasis among the poorly differentiated tumours, but this was not statistical significant.

\section{Smoking and alcohol}

Smoking and drinking habits of the 133 patients are listed in Table 1. As this was a retrospective study, it was not possible to specify the amount of tobacco and alcohol use in pack-years or units due to unstandardized reporting in the patients' files. As expected, there was a strong correlation between smoking and drinking $(\mathrm{p}=0.01)$, and a significant predominance of men among both smokers and drinkers $(\mathrm{p}<0.001)$. Compared to non-smokers and abstinent patients, smokers and drinkers presented with significantly larger tumours $(\mathrm{p}=0.002$ for smoking, $\mathrm{p}=0.017$ for drinking) and a higher frequency of regional node spread of the disease $(\mathrm{p}<0.001$ for smoking, $\mathrm{p}=0.002$ for drinking). There was a highly significant correlation between smoking and drinking and SOD $(\mathrm{p}<0.001)$.

For the whole cohort, there was also a highly significant correlation between both smoking and drinking and primary site ( $\mathrm{p}<0.001$ for both). $36 \%$ of the patients with tumours in the mobile tongue were smokers compared to $73 \%$ of the patients with tumours arising in floor of mouth. Only $8 \%$ of the patients with tongue cancers were recorded to be drinking more than once a week or daily compared to $40 \%$ of patients with cancers in the floor of the mouth. When stratified on gender, the correlation between smoking and primary site was statistically significant for both men and women $(\mathrm{p}=0.047$ and $\mathrm{p}=0.007$ respectively), but only women showed a statistically significant correlation between drinking habits and primary site ( $\mathrm{p}=0.017$ vs. 0.061 for men) (Table 2).

\section{HPV-related tumours}

p16 expression is often used as an indirect indicator of HPV infection in the tumour cells in clinical practice [32]. Of the 114 patients that we assessed for p16 expression in their primary tumour, 9\% were p16 positive (Table 1). For 16 of the patients, tissue from lymph node metastasis were also stained, which showed that p16 expression in the primary tumours and the metastatic foci correlated completely ( 2 positive/14 negative). There was no correlation between p16-status and 5 years survival rate, site of tumor or any of the other clinicopathological variables.

\section{Mortality}

As expected, we found that tumour size, presence of regional lymph node metastasis, as well as the compounded factor SOD, correlated with DSD $(p<0.001, p=0.001$ and $\mathrm{p}<0.001$, respectively, Figure 2). Furthermore, high alcohol consumption increased the 5-years risk of dying of the disease, both for the whole cohort $(p=0.002)$ and when stratified on men and women $(\mathrm{p}=0.039$ and $\mathrm{p}=0.001)$. None of the other variables showed any statistically significant association with 5-year DSD.

In a multivariate Cox regression analyses, including primary site, SOD, smoking and drinking, only SOD was significant for the whole cohort. Though, when evaluating genders separately, also drinking habits and the Integrading risk factors (IRF) variable were independent prognostic factors in women $(\mathrm{p}=0.01$ and $\mathrm{p}=0.02$, respectively).

\section{Discussion}

We have demonstrated that our North Norwegian cohort of patients with oral cancer is comparable with other groups investigated in international studies in most aspects. 
Table 2 Smoking and alcohol consume in relation to primary site

\begin{tabular}{|c|c|c|c|c|c|}
\hline Men & Mobile tounge & Floor of mouth & Alveolar rim & Other $^{a}$ & $\mathrm{p}^{*}$ \\
\hline Total & 34 (49\%) & $21(30 \%)$ & $9(13 \%)$ & $5(7 \%)$ & \\
\hline \multicolumn{6}{|l|}{ Smoking } \\
\hline Never & 7 (21\%) & $1(5 \%)$ & 0 & 0 & \multirow[t]{4}{*}{$p=0.04$} \\
\hline Previous & $8(24 \%)$ & $2(10 \%)$ & $2(22 \%)$ & $2(40 \%)$ & \\
\hline Smoker & $17(50 \%)$ & 17 (81\%) & $6(67 \%)$ & $1(20 \%)$ & \\
\hline Unknown & $2(6 \%)$ & $1(5 \%)$ & $1(11 \%)$ & $2(40 \%)$ & \\
\hline \multicolumn{6}{|l|}{ Drinking } \\
\hline Never & $4(12 \%)$ & $1(5 \%)$ & 0 & 0 & \multirow[t]{5}{*}{$p=0.061$} \\
\hline$<$ once a week & $18(53 \%)$ & $4(19 \%)$ & $4(44 \%)$ & $1(20 \%)$ & \\
\hline > once a week & $2(6 \%)$ & $6(29 \%)$ & $1(11 \%)$ & 0 & \\
\hline Daily & $2(6 \%)$ & $5(24 \%)$ & 0 & $1(20 \%)$ & \\
\hline Unknown & $8(24 \%)$ & $5(24 \%)$ & $4(44 \%)$ & $3(60 \%)$ & \\
\hline Women & Mobile tounge & Floor of mouth & Alveolar rim & Other $^{\mathrm{a}}$ & $p^{*}$ \\
\hline Total & $27(42 \%)$ & $9(14 \%)$ & 15 (23\%) & $13(20 \%)$ & \\
\hline \multicolumn{6}{|l|}{ Smoking } \\
\hline Never & $17(63 \%)$ & $1(11 \%)$ & $6(40 \%)$ & $3(23 \%)$ & \multirow[t]{4}{*}{$p=0.007$} \\
\hline Previous & $3(11 \%)$ & 1 (11\%) & $1(7 \%)$ & $1(8 \%)$ & \\
\hline Smoker & $5(19 \%)$ & $5(56 \%)$ & $1(7 \%)$ & $7(54 \%)$ & \\
\hline Unknown & $2(7 \%)$ & $2(22 \%)$ & $7(47 \%)$ & $2(15 \%)$ & \\
\hline \multicolumn{6}{|l|}{ Drinking } \\
\hline Never & $14(52 \%)$ & 0 & $6(40 \%)$ & $3(23 \%)$ & \multirow[t]{5}{*}{$p=0.017$} \\
\hline$<$ once a week & $9(33 \%)$ & $5(56 \%)$ & $2(13 \%)$ & $4(31 \%)$ & \\
\hline > once a week & 0 & $1(11 \%)$ & 0 & 0 & \\
\hline Daily & $1(4 \%)$ & 0 & $2(13 \%)$ & $2(15 \%)$ & \\
\hline Unknown & $3(11 \%)$ & $3(33 \%)$ & $4(27 \%)$ & $4(31 \%)$ & \\
\hline
\end{tabular}

${ }^{*} p<0.05$ was regarded as statistically significant, and highlighted in boldface when present.

ancludes buccal mucosa, palate and unspecified site in the oral cavity.

As reported in other studies, the majority of the patients presented with well or moderately differentiated tumours, most frequently located in the mobile tongue, floor of mouth and alveolar rim $[1,35]$. As reported in a North American study by Koch et al., we found that the smokers and drinkers were diagnosed between the fifth and seventh decades of life [12]. There were less smokers and drinkers among the youngest and oldest individuals, who frequently presented tumours in the mobile tongue. This is also consistent with previous published data [12]. Tumours arising in the floor of mouth were by far more frequent in male patients with a high consume of both tobacco and alcohol (Table 2). This has also been reported by others, and has been explained by the accumulation of carcinogens in the mucus in the floor of the mouth $[1,12]$.

Our results indicate that alcohol is a more potent risk factor for development of OSCC than smoking. La Vecchia et al. [7] claims that alcohol has a major relevance in defining the individual risk of oral cancer. They describe a rising trend in oral cancer up to the mid 1990 in Europe, reflecting the expanding epidemic of all tobacco-related neoplasms in those countries. Though, over the last decades there has been a fall in lung cancer, but a persistent unfavourable trend in oral cancer in males from the UK, essentially attributable to changes in alcohol habits. Furthermore, we found that the correlation between drinking and DSD was stronger in women than in men. In the multivariate analysis, increased alcohol consumption was a significant risk factor for disease specific death in women, but not in men or the whole cohort. Other studies have also claimed that women are more vulnerable to the harmful effects of alcohol than men [36].

In our study we found a male/female ratio of 1.1, which is somewhat lower than reports from other countries in Northern Europe, like Denmark and the UK, where the ratio vary between 1.3 to $2.0[4,6,37]$. There is however a global trend of decreasing differences between genders $[3,8]$. The Cancer registry of Norway, which publish data in cancer incidence, mortality, survival and prevalence in 


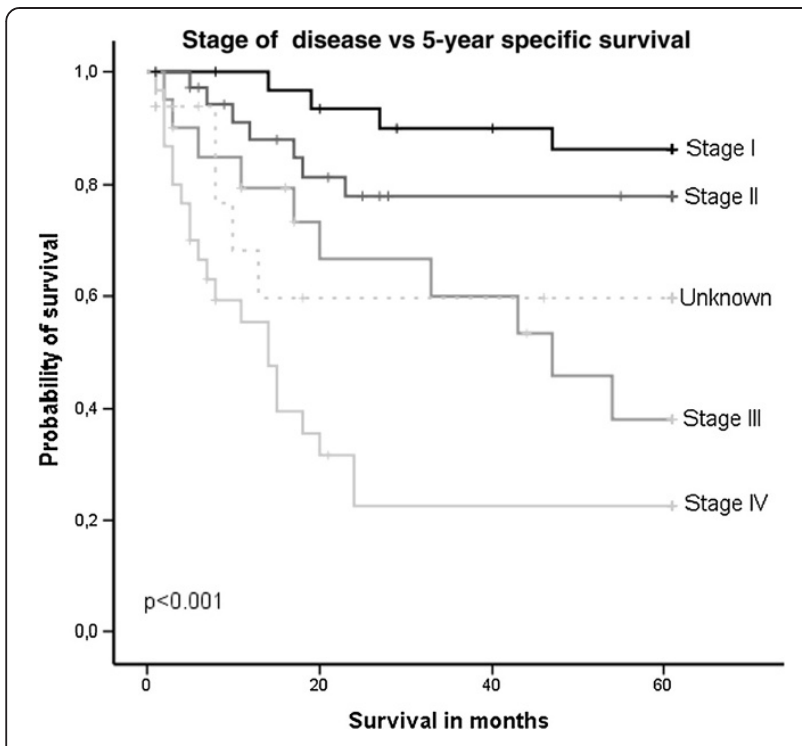

Figure 2 Kaplan Meier curve illustrating the disease specific survival in relation to stage of disease (SOD).

Norway, reports (for 1995) a 2.1:1 ratio for men versus women for cancer categorized as mobile tongue and mouth (3.0 and 1.4/100 000) (ICD-O, C02-C06) [33]. However, for the three northernmost counties in Norway, representing our impact area, the ratio in the national statistics was $1.3: 1$ (2.6 and 2.0/100 000) which is in accordance with the distribution found in our study. Thus the North Norwegian population does indeed seem to have a slightly lower ratio between men and women than reported elsewhere.

According to available data for alcohol consumption in Norway in 1999, men consumed 4.82 litres of pure alcohol per year (35\% classified as hard liquor), and women 1.94 (20\% hard liquor) [38]. The numbers in the three northernmost counties did not differ much from the rest of Norway [39]. There are no reliable studies reporting amount and type of alcohol consumed in men and women in the different regions of Norway, although many speculate that moonshine (illegally distillate spirits) is consumed to a somewhat larger degree by both genders in the northern part of Norway. Several studies have shown that hard liquor have a larger impact on OSCC-development than wine and beer $[13,40,41]$.

In our material, which is not adjusted for age, there was a tendency for an increased proportion of women in the higher age-groups. Statistics of Norway reveal that in 1995 women in Norway had an overall 6 year longer life expectancy then men [42]. This longer life-expectancy for women, and the lack of adjustment for this in our material, might explain that the male/female ratio was somewhat low, despite the fact that men drank significantly more than women.
The 5-year risk for DSD was 35\% for the whole cohort, $41 \%$ for the men and $30 \%$ for the women respectively, which is somewhat lower than often reported $[43,44]$. The difference between men and women was not statistically significant. The majority of the patients in our study were diagnosed with an early stage disease, presenting with small (T1 $(30 \%)$ or T2 (33\%)) primary tumours and 82 out of 133 patients (62\%) without detectable lymph node metastasis. This may in part be due to a wellfunctioning health-care system providing easy access and good treatment prospects. Women were in general diagnosed with smaller tumours than men, which suggest that they are diagnosed at an earlier stage of tumour development. The longer survival could partly be a result of earlier diagnosis, and not the fact that women survive longer than men (lead time bias).

In 2001, Mork et al. [28], reported the proportion of HPV-related tumours in the oral cavity of Scandinavian head and neck-cancer patients to be $6.8 \%$. This correlates well with our numbers where $8.7 \%$ of the tumours were p16 positive. However, in the study by Mork, all of the HPV-positive tumours arose in the mobile tongue, giving a frequency of $14 \%$ at this specific site. In our material there was a small, but not statistically significant difference in p16-positivity in tumours of the mobile tongue (11\%) compared to the rest of the oral cavity (7\%). In most studies, HPV-positivity has been found to correlate with a favourable prognosis for carcinomas in the oropharynx, but in line with our results, such a correlation are seldom reported for carcinomas in the oral cavity or other sub sites in the head and neck region $[29,45]$. There has also been reported a higher degree of HPV-negative carcinomas among smokers [12], but there was no such tendency in our material.

\section{Conclusion}

Our study confirms that the North Norwegian OSCC patient is representative of the general OSCC patient in Europe, both regarding primary site, the stage of the disease and associations with risk factors such as smoking and drinking. This is important when considering the applicability of results from biomarker studies performed on this material to other cohorts. Likewise, results from other studies can be applicable for the population of Northern Norway.

\section{Competing interests}

The authors declare that they have no competing interests.

\section{Authors' contributions}

OR has contributed to the conception and design of the study, collected data, analysed and interpreted the data, drafted and later revised the manuscript. IHB has participated in the design of the study, interpreted the data, and revised the manuscript. LUH has been central in the conception and design of the study, interpreting the data, and revised the manuscript. $\mathrm{EHO}$ has participated in the design of the study, critically interpreted the data, and revised the manuscript. SES has contributed to the conception and 
design of the study, analysed and interpreted the data, drafted and revised the manuscript. All authors have given their final approval of the version to be published.

\section{Acknowledgements}

All authors are funded by governmental non-profit organisations in Norway. $\mathrm{OR}$, IHB and SES are funded by The North Norwegian Health authorities, EHO by the UiT The Arctic University of Norway and LUH by both organisations. The study was supported by grants from The North Norwegian Health authorities.

\section{Author details}

'Department of Otorhinolaryngology, University Hospital of North Norway, Tromsø, Norway. ${ }^{2}$ Department of Medical Biology - Tumour Biology Research Group, UiT The Arctic University of Norway, Troms $\varnothing$, Norway. ${ }^{3}$ Diagnostic Clinic - Clinical Pathology, University Hospital of North Norway, Tromsø, Norway.

Received: 5 April 2014 Accepted: 30 July 2014 Published: 18 August 2014

\section{References}

1. Barnes LEJ, Reichart P, Sidransky D: WHO. Pathology and Genetics of Head and Neck Tumours. Lyon: IARC Press; 2005.

2. Davies AN, Epstein JB: Oral Complications of Cancer and its Management New York: Oxford University press; 2010

3. Warnakulasuriya S: Global epidemiology of oral and oropharyngeal cancer. Oral Oncol 2009, 45(4-5):309-316.

4. Oral cancer Incidence Statistics. Cancer Research UK; 2010. www. cancerresearchuk.org.

5. Cancer Registry of Norway: Cancer in Norway 2011 - Cancer incidence, mortality, survival and prevalence in Norway. Oslo: Cancer Registry of Norway; 2013.

6. Warnakulasuriya S: Living with oral cancer: epidemiology with particular reference to prevalence and life-style changes that influence survival. Oral Oncol 2010, 46(6):407-410.

7. La Vecchia C, Lucchini F, Negri E, Levi F: Trends in oral cancer mortality in Europe. Oral Oncol 2004, 40(4):433-439.

8. Franceschi S, Bidoli E, Herrero R, Muñoz N: Comparison of cancers of the oral cavity and pharynx worldwide: etiological clues. Oral Oncol 2000, 36(1):106-115

9. Ferreira Antunes JL, Toporcov TN, Biazevic MG, Boing AF, Scully C, Petti S: Joint and independent effects of alcohol drinking and tobacco smoking on oral cancer: a large case-control study. PLoS One 2013, 8(7):e68132.

10. Hashibe M, Brennan P, Benhamou S, Castellsague X, Chen C, Curado MP, Dal Maso L, Daudt AW, Fabianova E, Fernandez L, Wünsch-Filho V Franceschi S, Hayes RB, Herrero R, Koifman S, La Vecchia C, Lazarus P, Levi F, Mates D, Matos E, Menezes A, Muscat J, Eluf-Neto J, Olshan AF, Rudnai P. Schwartz SM, Smith E, Sturgis EM, Szeszenia-Dabrowska N, Talamini R et al. Alcohol drinking in never users of tobacco, cigarette smoking in never drinkers, and the risk of head and neck cancer: pooled analysis in the International Head and Neck Cancer Epidemiology Consortium. J Nat Cancer Inst 2007, 99(10):777-789.

11. Castellsague X, Quintana MJ, Martinez MC, Nieto A, Sanchez MJ, Juan A, Monner A, Carrera M, Agudo A, Quer M, Muñoz N, Herrero R, Franceschi S, Bosch FX: The role of type of tobacco and type of alcoholic beverage in oral carcinogenesis. Int J Cancer 2004, 108(5):741-749.

12. Koch WM, Lango M, Sewell D, Zahurak M, Sidransky D: Head and neck cancer in nonsmokers: a distinct clinical and molecular entity. Laryngoscope 1999, 109(10):1544-1551

13. Blot WJ, McLaughlin JK, Winn DM, Austin DF, Greenberg RS, Preston-Martin S, Bernstein L, Schoenberg JB, Stemhagen A, Fraumeni JF Jr: Smoking and drinking in relation to oral and pharyngeal cancer. Cancer Res 1988, 48(11):3282-3287

14. Guha N, Warnakulasuriya S, Vlaanderen J, Straif K: Betel quid chewing and the risk of oral and oropharyngeal cancers: a meta-analysis with implications for cancer control. Int J Cancer 2014, 135(6):1433-1443.

15. IARC: International Agency for Research on Cancer. Betel-Quid and Areca-Nut Chewing and Ome Areca-Nut Derived Nitrosamines. In IARC Monographs on the Evaluation of Carcinogenic Risk to Humans, Volume 85. Lyon: IARC; 2004
16. Shenoi R, Devrukhkar V, Sharma BK, Sapre SB, Chikhale A: Demographic and clinical profile of oral squamous cell carcinoma patients: $a$ retrospective study. Indian J Cancer 2012, 49(1):21-26.

17. Boffetta P, Mashberg A, Winkelmann R, Garfinkel L: Carcinogenic effect of tobacco smoking and alcohol drinking on anatomic sites of the oral cavity and oropharynx. Int J Cancer 1992, 52(4):530-533.

18. Dhar PK, Rao TR, Sreekumaran Nair N, Mohan S, Chandra S, Bhat KR, Rao K: Identification of risk factors for specific subsites within the oral and oropharyngeal region-a study of 647 cancer patients. Indian J Cancer 2000, 37(2-3):114-122.

19. Sobin L, Gospodarowicz M, Wittekind C: TNM Classification of Malignant Tumours. 7th edition. Chichester: Wiley-Blackwell; 2009.

20. Leemans $\mathrm{CR}$, Braakhuis BJ, Brakenhoff RH: The molecular biology of head and neck cancer. Nat Rev Cancer 2011, 11(1):9-22

21. Massano J, Regateiro FS, Januário G, Ferreira A: Oral squamous cell carcinoma: review of prognostic and predictive factors. Oral Surg Oral Med Oral Pathol Oral Radiol Endod 2006, 102(1):67-76.

22. Chen YK, Huang HC, Lin LM, Lin CC: Primary oral squamous cell carcinoma: an analysis of 703 cases in southern Taiwan. Oral Oncol 1999 35(2):173-179

23. Kademani D, Bell RB, Bagheri S, Holmgren E, Dierks E, Potter B, Homer L: Prognostic factors in intraoral squamous cell carcinoma: the influence of histologic grade. J Oral Maxillofac Surg 2005, 63(11):1599-1605.

24. Po Wing Yuen A, Lam KY, Lam LK, Ho CM, Wong A, Chow TL, Yuen WF, Wei Wl: Prognostic factors of clinically stage I and II oral tongue carcinoma-A comparative study of stage, thickness, shape, growth pattern, invasive front malignancy grading, Martinez-Gimeno score, and pathologic features. Head Neck 2002, 24(6):513-520.

25. Oc P, Pillai G, Patel S, Fisher C, Archer D, Eccles S, Rhys-Evans P: Tumour thickness predicts cervical nodal metastases and survival in early oral tongue cancer. Oral Oncol 2003, 39(4):386-390.

26. Fischer CA, Kampmann M, Zlobec I, Green E, Tornillo L, Lugli A, Wolfensberge $M$, Terracciano LM: 16 expression in oropharyngeal cancer: its impact on staging and prognosis compared with the conventional clinical staging parameters. Ann Oncol 2010, 21(10):1961-1966.

27. Ha PK, Pai SI, Westra WH, Gillison ML, Tong BC, Sidransky D, Califano JA: Real-time quantitative PCR demonstrates low prevalence of human papillomavirus type 16 in premalignant and malignant lesions of the oral cavity. Clin Cancer Res: J Am Assoc Cancer Res 2002, 8(5):1203-1209.

28. Mork J, Lie AK, Glattre E, Hallmans G, Jellum E, Koskela P, Moller B, Pukkala E, Schiller JT, Youngman L, Lehtinen M, Dillner J: Human papillomavirus infection as a risk factor for squamous-cell carcinoma of the head and neck. N Engl J Med 2001, 344(15):1125-1131.

29. Poling JS, Ma XJ, Bui S, Luo Y, Li R, Koch WM, Westra WH: Human papillomavirus (HPV) status of non-tobacco related squamous cell carcinomas of the lateral tongue. Oral Oncol 2014, 50(4):306-310.

30. Singhi $A D$, Westra $W H$ : Comparison of human papillomavirus in situ hybridization and p16 immunohistochemistry in the detection of human papillomavirus-associated head and neck cancer based on a prospective clinical experience. Cancer 2010, 116(9):2166-2173.

31. El-Naggar AK, Westra WH: p16 expression as a surrogate marker for HPVrelated oropharyngeal carcinoma: a guide for interpretative relevance and consistency. Head Neck 2012, 34(4):459-461.

32. Fregonesi PA, Teresa DB, Duarte RA, Neto CB, de Oliveira MR, Soares CP: p16(INK4A) immunohistochemical overexpression in premalignant and malignant oral lesions infected with human papillomavirus. $J$ Histochem Cytochem 2003, 51(10):1291-1297.

33. International Classification of Diseases for Oncology. 3rd edition. WHO 2000. http://whqlibdoc.who.int/publications/2000/9241545348_eng.pdf

34. Greene FL, Page DL, Fleming ID, Fritz AG, Balch CM, Haler DG, Morrow M: AJCC Cancer Staging Manual. 6th edition. New York: NY: Springer; 2002.

35. Muller S, Pan Y, Li R, Chi AC: Changing trends in oral squamous cell carcinoma with particular reference to young patients: 1971-2006. The Emory University experience. Head Neck Pathol 2008, 2(2):60-66.

36. Wang C, Xue H, Wang Q, Hao Y, Li D, Gu D, Huang J: Effect of drinking on all-cause mortality in women compared with men: a meta-analysis. J Women's Health 2002, 2014:373-381.

37. Blomberg M, Nielsen A, Munk C, Kjaer SK: Trends in head and neck cancer incidence in Denmark, 1978-2007: focus on human papillomavirus associated sites. Int J Cancer 2011, 129(3):733-741. 
38. Rossow I: Drug consumtion in Norway (in Norwegian). Nork Epidemiologi 2002, 12(3):301-307.

39. Strand BH, Steiro A: Alcohol consumption by level og income and education in Norway 1993-2000 (in Norwegian). Tidsskrift for Den norske legeforening 2003, 123(20):2849-2853.

40. De Stefani E, Boffetta P, Oreggia F, Fierro L, Mendilaharsu M: Hard liquor drinking is associated with higher risk of cancer of the oral cavity and pharynx than wine drinking. A case-control study in Uruguay. Oral Oncol 1998, 34(2):99-104.

41. Oze I, Matsuo K, Wakai K, Nagata C, Mizoue T, Tanaka K, Tsuji I, Sasazuki S, Inoue M, Tsugane S: Alcohol drinking and esophageal cancer risk: an evaluation based on a systematic review of epidemiologic evidence among the Japanese population. Jpn J Clin Oncol 2011, 41(5):677-692.

42. Life Expectancy in Norway. Norwegian Institute of Public Health; 2014. http://www.ssb.no/en/befolkning/statistikker/dode.

43. Cancer Survival: England and Wales, Less Common Cancers by Age Groups. Office of National Statistics (ONS) 2005. www.ons.gov.uk.

44. Siegel R, Ward E, Brawley O, Jemal A: Cancer statistics, 2011: the impact of eliminating socioeconomic and racial disparities on premature cancer deaths. CA: Cancer J Clin 2011, 61(4):212-236.

45. Salazar CR, Smith RV, Garg MK, Haigentz M Jr, Schiff BA, Kawachi N, Anayannis N, Belbin TJ, Prystowsky MB, Burk RD, Schlecht NF: Human papillomavirus-associated head and neck squamous cell carcinoma survival: a comparison by tumor site and initial treatment. Head Neck Pathol 2013, 8(1):77-87.

doi:10.1186/1472-6831-14-103

Cite this article as: Rikardsen et al:: Clinicopathological characteristics of oral squamous cell carcinoma in Northern Norway: a retrospective study. BMC Oral Health 2014 14:103.

\section{Submit your next manuscript to BioMed Central and take full advantage of:}

- Convenient online submission

- Thorough peer review

- No space constraints or color figure charges

- Immediate publication on acceptance

- Inclusion in PubMed, CAS, Scopus and Google Scholar

- Research which is freely available for redistribution 